Supplementary Information for

\title{
Time Trends of Arctic Contamination in Relation to Emission History and Chemical Persistence and Partitioning Properties
}

\author{
TODD GOUIN, FRANK WANIA ${ }^{1}$
}

Department of Physical and Environmental Sciences, University of Toronto

Scarborough, 1265 Military Trail, Toronto, Ontario, Canada, M1C 1A4

\begin{tabular}{|l|l|l|}
\hline \multicolumn{1}{|l|}{ Content } & \multicolumn{1}{|l|}{} & Page \\
\hline Text & Globo-POP model description & S2 \\
\hline Text & $\begin{array}{l}\text { Discussion of the relevance of the model results for transport } \\
\text { pathways and time trends of persistent perfluroalkyl } \\
\text { compounds in the Arctic. }\end{array}$ & S7 \\
\hline Figure S1 to S6 & $\begin{array}{l}\text { 6 figures summarizing the } e \text { ACP values and temporal profiles } \\
\text { for 96 hypothetical chemicals, for each of the three emission } \\
\text { scenarios. }\end{array}$ & S9 \\
\hline Figure S7 & $\begin{array}{l}\text { 1 figure summarizing the } e \text { ACP for Chemical B, C, and D for } \\
\text { the bell curve emission scenario in which the influence of } \\
\text { degradation in surfaces is illustrated. }\end{array}$ & S16 \\
\hline Figure S8 & $\begin{array}{l}\text { 1 figure showing the influence of setting the oceanic advection } \\
\text { term to zero on the eACP for the most persistent chemicals B } \\
\text { and D. }\end{array}$ & S17 \\
\hline
\end{tabular}

\footnotetext{
${ }^{1}$ Corresponding author phone: (416)287-7225; e-mail: frank.wania@utoronto.ca.
} 


\section{Description of Globo-POP Model Used in eACP Calculations}

The Globo-POP model (global distribution model for persistent organic pollutants software program, version 1.1) used in this study is freely available at www.utsc.utoronto.ca/ wania after obtaining a password from Frank Wania (frank.wania@utoronto.ca). Equations and environmental inputs for the model are described by Wania and Mackay (1), with the most recent updates to the model described by Wania et al. (2). The environmental default settings were used in all calculations, except where sensitivity calculations were performed to assess the influence of the oceans on $e \mathrm{ACP}$ and lag time, as discussed in the main text of this study.

The Globo-POP model consists of 10 climate zones as shown in Figure SA. Transport between the zones occurs via atmospheric advection and oceanic mixing. Tables SA - SE describe the environmental and transport parameters used in the default Globo-POP model environment.

\section{Globo-POP model environment}
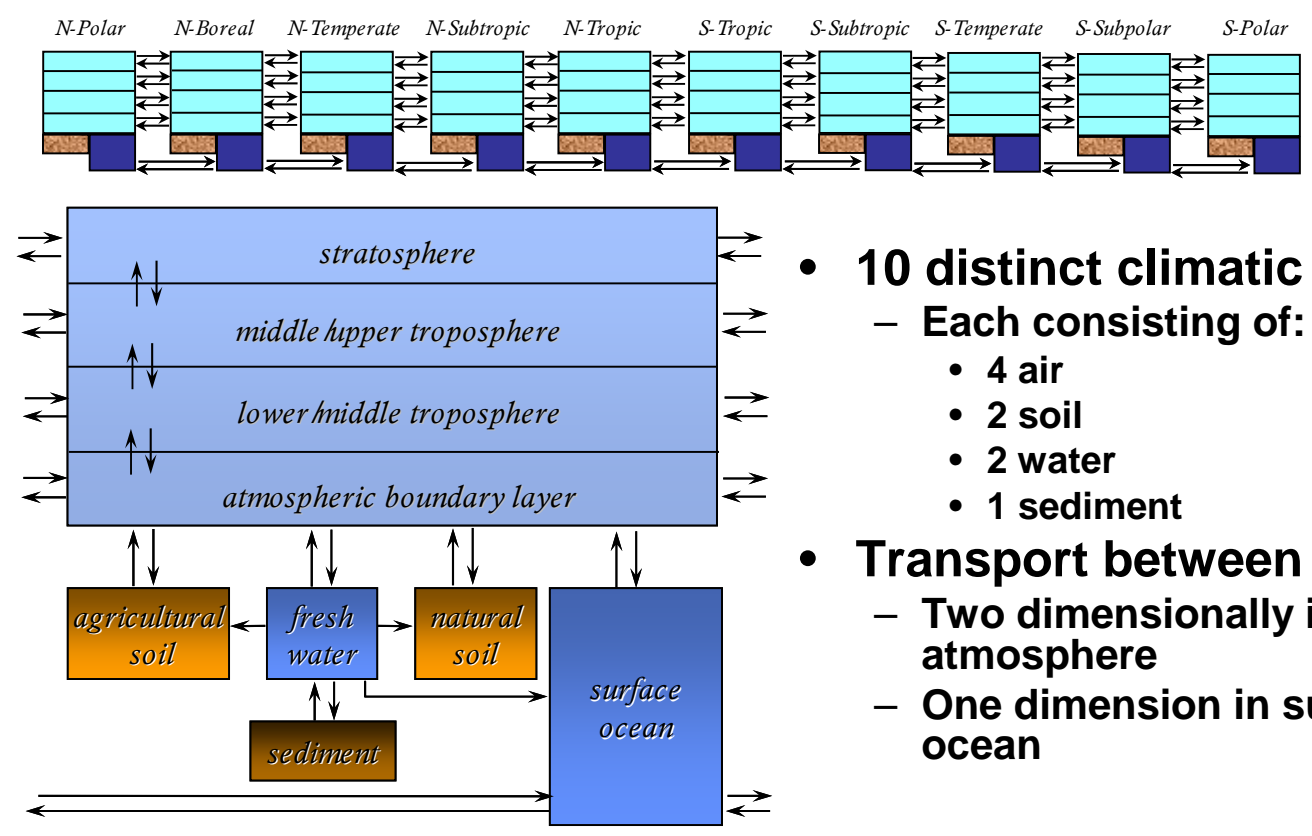

- 10 distinct climatic zones

- Each consisting of:

- 4 air

- 2 soil

- 2 water

- 1 sediment

- Transport between zones

- Two dimensionally in the atmosphere

- One dimension in surface ocean

Figure SA: Schematic of the Globo-POP model environment 
Table SA: Globo-POP default environmental parameters

\begin{tabular}{l|ll|lllll}
\hline Zone & \multicolumn{3}{|c|}{ Area Fractions } & \multicolumn{5}{c}{ Depths in m } \\
\hline & $\begin{array}{l}\text { Fresh water } \\
\text { coverage of } \\
\text { land area }\end{array}$ & $\begin{array}{l}\text { Cultivated } \\
\text { fraction of } \\
\text { land area }\end{array}$ & $\begin{array}{l}\text { Cult. } \\
\text { soil }\end{array}$ & $\begin{array}{l}\text { Uncult. } \\
\text { soil }\end{array}$ & $\begin{array}{l}\text { Surface } \\
\text { Ocean }\end{array}$ & $\begin{array}{l}\text { Fresh } \\
\text { water }\end{array}$ & $\begin{array}{l}\text { Fresh } \\
\text { water } \\
\text { sediment }\end{array}$ \\
\hline N-Polar & 0.035 & 0.0001 & 0.02 & 0.02 & 200 & 20 & 0.05 \\
N- Boreal & 0.05 & 0.01 & 0.1 & 0.05 & 200 & 20 & 0.05 \\
N- Temperate & 0.05 & 0.15 & 0.2 & 0.05 & 200 & 20 & 0.05 \\
N-Subtropic & 0.025 & 0.1 & 0.2 & 0.05 & 200 & 20 & 0.05 \\
N- Tropic & 0.03 & 0.05 & 0.2 & 0.05 & 200 & 20 & 0.05 \\
S-Tropic & 0.05 & 0.05 & 0.2 & 0.05 & 200 & 20 & 0.05 \\
S-Subtropic & 0.025 & 0.1 & 0.2 & 0.05 & 200 & 20 & 0.05 \\
S-Temperate & 0.025 & 0.15 & 0.2 & 0.05 & 200 & 20 & 0.05 \\
S-Subpolar & 0.005 & 0.0001 & 0.02 & 0.05 & 200 & 20 & 0.05 \\
S-Polar & 0.005 & 0.0001 & 0.02 & 0.02 & 200 & 20 & 0.05 \\
\hline
\end{tabular}

Table SB: Globo-POP default air-surface exchange parameters

\begin{tabular}{|c|c|c|c|c|c|c|c|c|}
\hline \multirow[t]{2}{*}{ Zone } & \multicolumn{2}{|c|}{$\begin{array}{c}\text { Dry particle } \\
\text { deposition } \\
\text { velocities }(\mathrm{m} / \mathrm{h})\end{array}$} & \multirow[t]{2}{*}{$\begin{array}{l}\text { Particle } \\
\text { scaveng. } \\
\text { ratio }\end{array}$} & \multicolumn{3}{|c|}{$\begin{array}{l}\text { Diffusive air-surface mass } \\
\text { transfer coefficients }(\mathrm{m} / \mathrm{h})\end{array}$} & \multicolumn{2}{|c|}{$\begin{array}{c}\text { Solid phase } \\
\text { diffusivity }\left(\mathrm{m}^{2} / \mathrm{h}\right)\end{array}$} \\
\hline & $\begin{array}{l}\text { over } \\
\text { land }\end{array}$ & $\begin{array}{l}\text { over } \\
\text { oceans }\end{array}$ & & $\begin{array}{l}\mathrm{S} / \mathrm{A} \text { air } \\
\text { side }\end{array}$ & $\begin{array}{l}\text { A/W } \\
\text { air } \\
\text { side }\end{array}$ & $\begin{array}{l}\mathrm{A} / \mathrm{W} \\
\text { water } \\
\text { side }\end{array}$ & $\begin{array}{l}\text { Cultiv } \\
\text { soil } \\
\text { solids }\end{array}$ & $\begin{array}{l}\text { Uncultiva } \\
\mathrm{t} \text { soil } \\
\text { solids }\end{array}$ \\
\hline N-Polar & 5.0 & 10.0 & 100000 & 2.5 & 2.5 & 0.025 & $5.7 \mathrm{E}-9$ & $5.7 \mathrm{E}-9$ \\
\hline N- Boreal & 5.0 & 5.0 & 100000 & 5.0 & 5.0 & 0.05 & $2.3 \mathrm{E}-8$ & $2.28 \mathrm{E}-8$ \\
\hline N- Temperate & 10.0 & 15.0 & 100000 & 5.0 & 5.0 & 0.05 & $2.3 \mathrm{E}-8$ & $2.28 \mathrm{E}-8$ \\
\hline N-Subtropic & 15.0 & 10.0 & 100000 & 2.5 & 2.5 & 0.025 & $2.3 \mathrm{E}-8$ & $2.28 \mathrm{E}-8$ \\
\hline N- Tropic & 15.0 & 10.0 & 100000 & 7.5 & 7.5 & 0.075 & $2.3 \mathrm{E}-8$ & $2.28 \mathrm{E}-8$ \\
\hline S-Tropic & 10.0 & 5.0 & 100000 & 7.5 & 7.5 & 0.075 & $2.3 \mathrm{E}-8$ & $2.28 \mathrm{E}-8$ \\
\hline S-Subtropic & 15.0 & 5.0 & 100000 & 2.5 & 2.5 & 0.025 & $2.3 \mathrm{E}-8$ & $2.28 \mathrm{E}-8$ \\
\hline S-Temperate & 10.0 & 10.0 & 100000 & 7.5 & 7.5 & 0.075 & $2.3 \mathrm{E}-8$ & $2.28 \mathrm{E}-8$ \\
\hline S-Subpolar & 5.0 & 10.0 & 100000 & 10.0 & 10.0 & 0.1 & $2.3 \mathrm{E}-8$ & $2.28 \mathrm{E}-8$ \\
\hline S-Polar & 5.0 & 10.0 & 100000 & 10.0 & 10.0 & 0.1 & $5.7 \mathrm{E}-9$ & 5.7E-9 \\
\hline
\end{tabular}


Table SC: Globo-POP default transport in water parameters

\begin{tabular}{l|cccc|ccc}
\hline Zone & \multicolumn{5}{c|}{ Fresh water } & \multicolumn{3}{c}{ Ocean water } \\
\hline & $\begin{array}{c}\text { Sedi } \\
\text { ment } \\
\text { water } \\
\text { MTC }\end{array}$ & $\begin{array}{c}\text { Deposit. } \\
\text { rate }\end{array}$ & $\begin{array}{c}\text { Resusp. } \\
\text { rate }\end{array}$ & $\begin{array}{c}\text { Burial } \\
\text { rate }\end{array}$ & $\begin{array}{c}\text { Particle } \\
\text { settling } \\
\text { rate }\end{array}$ & $\begin{array}{c}\text { Surface } \\
\text { deep ocean } \\
\text { MTC }\end{array}$ & $\begin{array}{c}\text { Horizontal } \\
\text { eddy } \\
\text { diffusion } \\
\text { coeff. } \\
\left(\mathrm{m}^{2} / \mathrm{h}\right)\end{array}$ \\
\hline N-Polar & 0.001 & $2.0 \mathrm{E}-7$ & $8.0 \mathrm{E}-8$ & $8.0 \mathrm{E}-8$ & $2.25 \mathrm{E}-8$ & $3.044 \mathrm{E}-4$ & \\
N-Boreal & 0.001 & $5.0 \mathrm{E}-7$ & $2.0 \mathrm{E}-7$ & $2.0 \mathrm{E}-7$ & $1.65 \mathrm{E}-8$ & $2.283 \mathrm{E}-4$ & $1.89 \mathrm{E}+7$ \\
N-Temperate & 0.001 & $5.0 \mathrm{E}-7$ & $2.0 \mathrm{E}-7$ & $2.0 \mathrm{E}-7$ & $3.60 \mathrm{E}-8$ & $2.283 \mathrm{E}-4$ & $1.00 \mathrm{E}+7$ \\
N-Subtropic & 0.001 & $5.0 \mathrm{E}-7$ & $2.0 \mathrm{E}-7$ & $2.0 \mathrm{E}-7$ & $1.32 \mathrm{E}-8$ & $2.283 \mathrm{E}-4$ & $1.30 \mathrm{E}+7$ \\
N-Tropic & 0.001 & $5.0 \mathrm{E}-7$ & $2.0 \mathrm{E}-7$ & $2.0 \mathrm{E}-7$ & $1.0 \mathrm{E}-8$ & $2.283 \mathrm{E}-4$ & $1.45 \mathrm{E}+7$ \\
S-Tropic & 0.001 & $5.0 \mathrm{E}-7$ & $2.0 \mathrm{E}-7$ & $2.0 \mathrm{E}-7$ & $1.0 \mathrm{E}-8$ & $2.283 \mathrm{E}-4$ & $1.975 \mathrm{E}+7$ \\
S-Subtropic & 0.001 & $5.0 \mathrm{E}-7$ & $2.0 \mathrm{E}-7$ & $2.0 \mathrm{E}-7$ & $1.65 \mathrm{E}-8$ & $2.283 \mathrm{E}-4$ & $1.20 \mathrm{E}+7$ \\
S-Temperate & 0.001 & $5.0 \mathrm{E}-7$ & $2.0 \mathrm{E}-7$ & $2.0 \mathrm{E}-7$ & $1.65 \mathrm{E}-8$ & $2.283 \mathrm{E}-4$ & $1.20 \mathrm{E}+7$ \\
S-Subpolar & 0.001 & $2.0 \mathrm{E}-7$ & $8.0 \mathrm{E}-8$ & $8.0 \mathrm{E}-8$ & $1.0 \mathrm{E}-8$ & $2.283 \mathrm{E}-4$ & $1.80 \mathrm{E}+7$ \\
S-Polar & 0.001 & $2.0 \mathrm{E}-7$ & $8.0 \mathrm{E}-8$ & $8.0 \mathrm{E}-8$ & $1.5 \mathrm{E}-9$ & $2.283 \mathrm{E}-4$ & $1.80 \mathrm{E}+7$ \\
\hline
\end{tabular}

Table SD: Globo-POP default rain and run-off rates

\begin{tabular}{l|ll|ll|ll}
\hline Zone & \multicolumn{2}{|c|}{$\begin{array}{c}\text { Fraction of rain } \\
\text { originating in }\end{array}$} & \multicolumn{2}{c|}{ Rain Rate $(\mathrm{cm} / \mathrm{yr})$} & \multicolumn{2}{c}{ Run-off rates } \\
\hline & $\begin{array}{l}\text { bottom } \\
\text { air layer }\end{array}$ & $\begin{array}{l}\text { second } \\
\text { lowest air } \\
\text { layer }\end{array}$ & $\begin{array}{l}\text { over } \\
\text { continents }\end{array}$ & $\begin{array}{l}\text { over } \\
\text { oceans }\end{array}$ & $\begin{array}{l}\text { fraction of } \\
\text { precip to run- } \\
\text { off to fresh } \\
\text { water }\end{array}$ & $\begin{array}{l}\text { fraction of } \\
\text { precip to run- } \\
\text { off to ocean }\end{array}$ \\
\hline N-Polar & 0.32 & 0.59 & 20.0 & 28.0 & 0.75 & 0.65 \\
N-Boreal & 0.3 & 0.6 & 50.0 & 90.0 & 0.6 & 0.5 \\
N-Temperate & 0.28 & 0.56 & 50.0 & 113.0 & 0.45 & 0.4 \\
N-Subtropic & 0.26 & 0.55 & 60.0 & 85.0 & 0.2 & 0.1 \\
N-Tropic & 0.24 & 0.5 & 113.0 & 150.0 & 0.35 & 0.275 \\
S-Tropic & 0.24 & 0.5 & 142.0 & 115.0 & 0.35 & 0.275 \\
S-Subtropic & 0.26 & 0.55 & 60.0 & 95.0 & 0.2 & 0.1 \\
S-Temperate & 0.28 & 0.56 & 118.0 & 128.0 & 0.45 & 0.4 \\
S-Subpolar & 0.32 & 0.59 & 50.0 & 75.0 & 0.85 & 0.75 \\
S-Polar & 0.32 & 0.59 & 50.0 & 75.0 & 0.85 & 0.75 \\
\hline
\end{tabular}


Table SE: Phase residence times due to advective movement

\begin{tabular}{|c|c|c|c|c|c|c|c|}
\hline Zone & 1 & $2^{\mathrm{Ai}}$ & $\begin{array}{l}(\mathrm{d}) \\
3\end{array}$ & 4 & $\begin{array}{l}\text { Sea } \\
\text { water } \\
(\mathrm{yr})\end{array}$ & $\begin{array}{l}\text { Fresh } \\
\text { water } \\
\text { (d) }\end{array}$ & $\begin{array}{l}\text { Sediment } \\
(\mathrm{yr})\end{array}$ \\
\hline N-Polar & 6.708 & 8.433 & 36.50 & 882 & 25.03 & 1965 & 71.35 \\
\hline N-Boreal & 4.222 & 5.805 & 26.01 & 290 & 3.136 & 1460 & 28.54 \\
\hline N-Temperate & 4.873 & 7.919 & 41.41 & 251 & 10.05 & 1825 & 28.54 \\
\hline N-Subtropic & 3.931 & 6.828 & 27.99 & 129 & 9.980 & 3042 & 28.54 \\
\hline N-Tropic & 3.905 & 5.945 & 27.19 & 305 & 20.03 & 705 & 28.54 \\
\hline S-Tropic & 2.853 & 4.168 & 20.44 & 351 & 20.02 & 935 & 28.54 \\
\hline S-Subtropic & 2.978 & 5.159 & 30.16 & 230 & 9.971 & 3042 & 28.54 \\
\hline S-Temperate & 2.410 & 3.905 & 26.22 & 221 & 5.081 & 387 & 28.54 \\
\hline S-Subpolar & 5.015 & 8.480 & 48.00 & 451 & 10.21 & 97.33 & 71.35 \\
\hline S-Polar & 5.338 & 9.216 & 42.96 & 499 & 5.305 & 97.33 & 71.35 \\
\hline
\end{tabular}

\section{Partitioning behavior - Temperature dependence}

Partitioning properties for each of the six chemicals are given in Table 1. The temperature dependence of the partitioning properties of all hypothetical chemicals was assumed to be the same and was expressed using the following energies of phase transfer:

- between octanol and water $\Delta \mathrm{U}_{\mathrm{OW}}=-20 \mathrm{~kJ} / \mathrm{mol}$

- between air and water $\Delta \mathrm{U}_{\mathrm{AW}}=60 \mathrm{~kJ} / \mathrm{mol}$

- between octanol and air $\Delta \mathrm{U}_{\mathrm{OA}}=-80 \mathrm{~kJ} / \mathrm{mol}$

From the input parameters the partition coefficients at the environmental temperature in the model are calculated as:

$\log \mathrm{K}_{\mathrm{AW}}(\mathrm{T})=\log \mathrm{K}_{\mathrm{AW}}\left(\mathrm{T}_{\mathrm{ref}}\right)+\Delta \mathrm{H}_{\mathrm{AW}} /((2.303) \mathrm{R})\left(1 / \mathrm{T}_{\text {ref }}-1 / \mathrm{T}\right)$

$\log \mathrm{K}_{\mathrm{OA}}(\mathrm{T})=\log \mathrm{K}_{\mathrm{OA}}\left(\mathrm{T}_{\mathrm{ref}}\right)+\Delta \mathrm{H}_{\mathrm{OA}} /((2.303) \mathrm{R})\left(1 / \mathrm{T}_{\text {ref }}-1 / \mathrm{T}\right)$

where $\mathrm{R}$ is the universal gas constant and $\mathrm{T}$ and $\mathrm{T}_{\text {ref }}$ refer to the temperature of the property at $25^{\circ} \mathrm{C}$ and the environmental temperature, respectively. 


\section{Degradation}

Degradation characteristics of the chemical in the environment are described by firstorder kinetics, and only the zonal parameter of temperature can influence degradation rates, except for degradation in air which includes zonal changes in $\mathrm{OH}$ radical concentrations.

Degradation in surface media. Degradation in water, soil, and sediment is assumed to include all degradation processes that an organic compound will undergo, including biodegradation, hydrolysis, and photolysis. Reaction half-lives in surface media were varied between 876 to 876000 hours as described in the main text. An activation energy $\mathrm{A}_{\text {ea }}$ of $30 \mathrm{~kJ} / \mathrm{mol}$ was assumed to apply to all degradation processes in surface media.

Degradation in air. Degradation in air is described by a first order rate constant $\left(\mathrm{k}_{\mathrm{ra}}\right)$ :

$\mathrm{k}_{\mathrm{ra}}=\mathrm{k}_{\mathrm{raref}} \cdot[\mathrm{OH}] \cdot 3600 \cdot \exp \left(\left(\mathrm{A}_{\mathrm{ea}} / \mathrm{R}\right)\left(1 / \mathrm{T}_{\mathrm{ref}}-1 / \mathrm{T}\right)\right)$

where $\mathrm{k}_{\mathrm{raref}}$ is the reference reaction rate (ranging from $10^{-15}$ to $10^{-12}$ molecule/ $\mathrm{h}$, as described in the methods section of the main text), $A_{e a}$ is the activation energy (10 $\mathrm{kJ} / \mathrm{mol}$ ), and $[\mathrm{OH}]$ is the concentration of hydroxyl radicals which has been parameterized for each climatic zones based on Rodriguez et al. (3)

\section{References}

1. Wania, F.; Mackay, D. A global distribution model for persistent organic chemicals. Sci. Total Environ. 1995, 161, 211-232.

2. Wania, F., Mackay, D., Li, Y-F, Bidleman, T.F., Strand, A. Global chemical fate of $\alpha$-hexachlorocylohexane. 1. Evaluation of a Global distribution model. Environ. Toxicol. Chem. 1999, 18, 1390-1399.

3. Rodriguez, J.M., Ko, M.K.W., Sze, N.D., Heisey, C.W. Impacts of biomass burning on tropospheric $\mathrm{CO}$ and $\mathrm{OH}$ : A two-dimensional study. In J.S. Levine (Ed.), Global Biomass Burning, Atmospheric, Climatic, and Biological Implications. The MIT Press, Cambridge, MA, 1992 p. 351-359. 


\section{Relevance for the Transport Pathways and Time Trends of Persistent Perfluoroalkyl Compounds in the Arctic.}

Initially, long range oceanic transport (LROT) was not considered of great relevance for bioaccumulating organic substances, presumably for two reasons. The polar functional entities that make a molecule more water soluble generally also enhance the molecule's reactivity in the physical environment and in biota. Considering that oceanic transport takes place on the time scale of multiple years and decades, it was believed that there are possibly no environmentally relevant organic chemicals that combine water solubility and persistence in water on the time scale of years. Similarly, based on the strong relationship between water solubility and $K_{\mathrm{OW}}$ on the one hand (1), and the relationship between $K_{\mathrm{OW}}$ and bioaccumulation potential in aquatic organisms on the other (2), it was assumed that any substance that is water soluble enough to undergo LROT would not bioaccumulate.

Perfluoroalkyl compounds with hydrophilic end groups have proven both these assumptions as fundamentally flawed. Chemicals, such as trifluoroacetic acid (TFA) and the perfluorinated carboxylic acids (PFCAs), are examples of substances that combine solubility and very high persistence in water (3-5). Unlike TFA, which has been found not to bioaccumulate in organisms due to its short chain length (5), there is increasing evidence that compounds such as the longer chain PFCAs are accumulating in organisms in both the Arctic $(6,7)$ and Antarctic (8), albeit not necessarily according to the lipidbased equilibrium partitioning mechanism of the classical bioaccumulating compounds. While there is an ongoing debate regarding the exact mechanism by which the PFCAs reach the polar regions, either via atmospheric degradation of the volatile fluorotelomer alcohol (FTOH) precursors (9) or through direct emissions of the PFCAs (4), the results from this study suggest that the physical-chemical properties of the PFCAs make them ideal candidates for contaminating the polar regions via LROT.

Given recent observations documenting the presence of perfluoralkyl compounds in remote regions, combined with the results shown in Figure 3, it thus seems reasonable to suggest that chemicals, which are both water soluble and highly persistent, should be scrutinized in terms of their potential for LROT. This is because these substances are likely to respond slowly to regulatory measures, with potential lag-times of nearly 3 decades.

A class of perfluoroalkyl compounds that may have properties necessary for multihopping, are the perfluorinated sulfonamido alcohols (FOSEs) and perfluorinated sulfonamides (PFOSAs), the presumed precursors of the perfluorinated sulfonic acids, such as perflurooctane sulfonate (PFOS) (10). Although the current physical-chemical property data for the FOSEs and PFOSAs are less well established than those of the FTOHs, the FOSEs and PFOSAs are believed to be somewhat less volatile (11), rendering them potentially susceptible to deposition at temperatures prevalent in the 
Arctic. In other words, whereas FTOHs are fliers, the FOSEs and PFOSAs may have characteristics of multi-hoppers. Multi-hoppers show a relatively large eACP, which suggests the possibility that the deposition and subsequent transformation of semi-volatile precursors may contribute to the loadings of PFOS to the Arctic. Thus, due to the potential importance of the atmospheric pathway for the PFOS precursors to the Arctic, combined with their relatively short half-life in air, it is conceivable that the ACP of PFOS will decline faster in response to regulatory activity than contamination with PFCAs such as PFOA, whose primary route to the Arctic may be via ocean currents $(4,12)$. This suggestion is consistent with empirical data $(7)$, in which it has been suggested that the disappearance half-lives of PFOS in liver samples collected from ringed seals in the Arctic is due to the phase out of the perfluoroctane sulfonyl fluoride based compounds in 2001. Continued monitoring of both PFCAs and PFOS in the Arctic will eventually demonstrate which of the two transport mechanisms is influencing the levels of each, but it seems plausible to suggest that the transport mechanisms of the PFCAs may differ from that of PFOS, simply because the physical-chemical properties of their precursors differ from one another. Indeed biological samples suggest that while levels of PFOS are showing rapid declines, with disappearance half-lives of approximately 4 years (7), the levels of the PFCAs are continuing to increase, with doubling times of between 4 and 13 years $(7,13)$.

\section{Literature Cited}

(1) Mackay, D.; Bobra, A.; Shiu, W. Y.; Yalkowsky, S. H. Relationships between Aqueous Solubility and Octanol-Water Partition-Coefficients. Chemosphere 1980, 9, 701-711.

(2) Mackay, D. Correlation of Bioconcentration Factors. Environ. Sci. Technol. 1982, 16, 274-278.

(3) Prevedouros, K.; Cousins, I. T.; Buck, R. C.; Korzeniowski, S. H. Sources, fate and transport of perfluorocarboxylates. Environ. Sci. Technol. 2006, 40, 32-44.

(4) Armitage, J.; Cousins, I. T.; Buck, R. C.; Prevedouros, K.; Russell, M. H.; MacLeod, M.; Korzeniowski, S. H. Modeling global-scale fate and transport of perfluorooctanoate emitted from direct sources. Environ. Sci. Technol. 2006, 40, 6969-6975.

(5) Boutonnet, J. C.; Bingham, P.; Calamari, D.; de Rooij, C.; Franklin, J.; Kawano, T.; Libre, J. M.; McCulloch, A.; Malinverno, G.; Odom, J. M.; Rusch, G. M.; Smythe, K.; Sobolev, I.; Thompson, R.; Tiedje, J. M. Environmental risk assessment of trifluoroacetic acid. Hum. Ecol. Risk Assess. 1999, 5, 59-124.

(6) Houde, M.; Martin, J. W.; Letcher, R. J.; Solomon, K. R.; Muir, D. C. G. Biological monitoring of polyfluoroalkyl substances: A review. Environ. Sci. Technol. 2006, 40, 3463-3473. 
(7) Butt, C. M.; Muir, D. C. G.; Stirling, I.; Kwan, M.; Mabury, S. A. Rapid response of Arctic ringed seals to changes in perfluoroalkyl production. Environ. Sci. Technol. 2007, 41, 42-49.

(8) Tao, L.; Kannan, K.; Kajiwara, N.; Costa, M. M.; Fillmann, G.; Takahashi, S.; Tanabe, S. Perfluorooctanesulfonate and related fluorochemicals in albatrosses, elephant seals, penguins, and Polar Skuas from the Southern Ocean. Environ. Sci. Technol. 2006, 40, 7642-7648.

(9) Wallington, T. J.; Hurley, M. D.; Xia, J.; Wuebbles, D. J.; Sillman, S.; Ito, A.; Penner, J. E.; Ellis, D. A.; Martin, J.; Mabury, S. A.; Nielsen, O. J.; Andersen, M. P. S. Formation of $\mathrm{C}_{7} \mathrm{~F}_{15} \mathrm{COOH}$ (PFOA) and other perfluorocarboxylic acids during the atmospheric oxidation of $8: 2$ fluorotelomer alcohol. Environ. Sci. Technol. 2006, 40, 924-930.

(10) Martin, J. W.; Ellis, D. A.; Mabury, S. A.; Hurley, M. D.; Wallington, T. J. Atmospheric chemistry of perfluoroalkanesulfonamides: Kinetic and product studies of the $\mathrm{OH}$ radical and $\mathrm{Cl}$ atom initiated oxidation of $\mathrm{N}$-ethyl perfluorobutanesulfonamide. Environ. Sci. Technol. 2006, 40, 864-872.

(11) Arp, H. P. H.; Niederer, C.; Goss, K.-U. Predicting the partitioning behavior of various highly fluorinated compounds. Environ. Sci. Technol. 2006, 40, 72987304.

(12) Wania, F. A global mass balance analysis of the source of perfluorocarboxylic acids in the Arctic Ocean. Environ. Sci. Technol. 2007, in press.

(13) Smithwick, M.; Norstrom, R. J.; Mabury, S. A.; Solomon, K.; Evans, T. J.; Stirling, I.; Taylor, M. K.; Muir, D. C. G. Temporal trends of perfluoroalkyl contaminants in polar bears (Ursus maritimus) from two locations in the North American Arctic, 1972-2002. Environ. Sci. Technol. 2006, 40, 1139-1143. 
Figure S1: Pulse emission scenario (solid grey bar indicates time to maximum eACP, white bar indicates the value of the maximum eACP, for chemicals SH, SW, MO, MM, and MT.)

Reference half-life for degradation in surface media
0.1 years
1 year
10 years
100 years

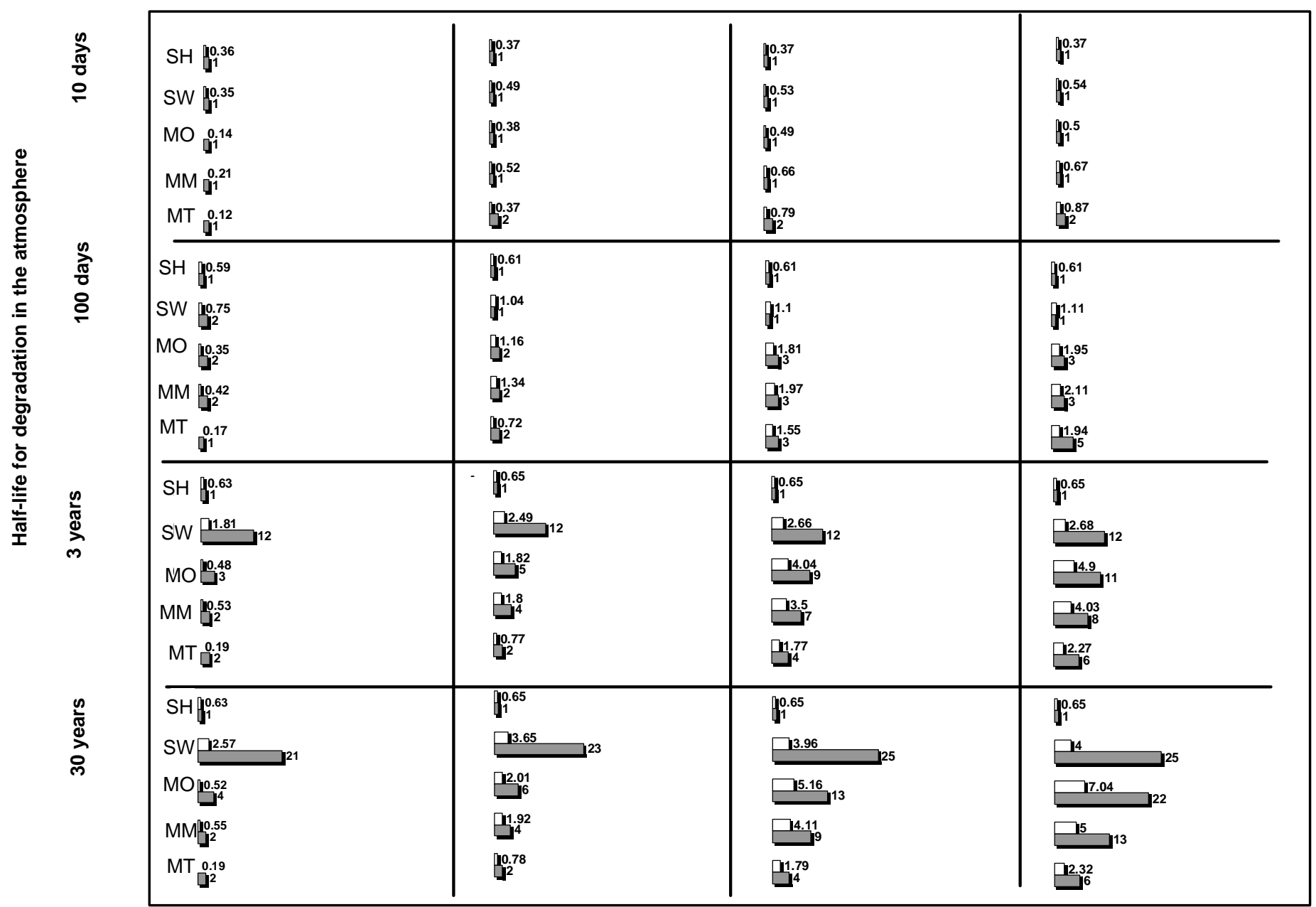


Figure S2: Temporal profile of the $e \mathrm{ACP}$ for the pulse emission scenario.

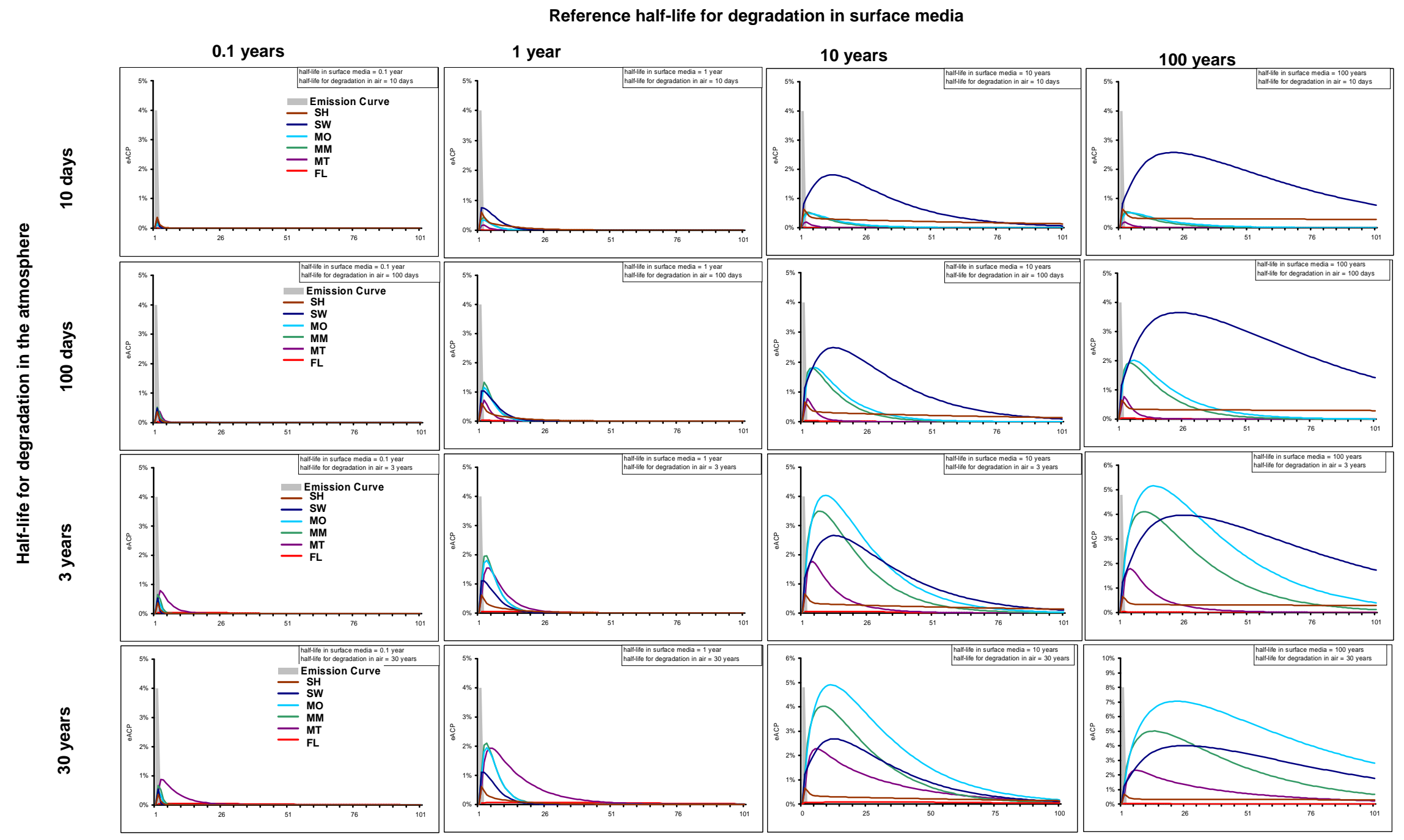


Figure S3: Bell curve emission scenario (solid grey bar indicates time to maximum eACP, white bar indicates the value of the maximum $e \mathrm{ACP}$, for chemicals $\mathrm{SH}, \mathrm{SW}, \mathrm{MO}, \mathrm{MM}$, and MT)

Reference half-life for degradation in surface media

\begin{tabular}{|c|c|c|c|c|}
\hline & 0.1 years & 1 year & 10 years & 100 years \\
\hline 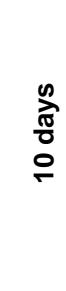 & 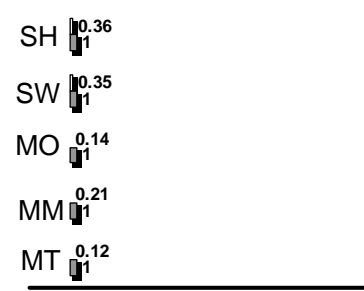 & $\begin{array}{l}\|_{1}^{0.37} \\
\|_{1}^{0.49} \\
\|_{1}^{0.38} \\
\|_{1}^{0.52} \\
0.52 \\
0.35 \\
0.23\end{array}$ & $\begin{array}{l}\prod_{1}^{0.37} \\
\prod_{1}^{0.53} \\
\prod_{1}^{0.49} \\
\prod_{1}^{0.66} \\
\prod_{1}^{0.63} \\
\end{array}$ & $\begin{array}{l}\prod_{12}^{0.37} \\
\prod_{12}^{0.54} \\
\prod_{12}^{0.5} \\
\prod_{1}^{0.67} \\
\prod_{0.72}^{0.72} \\
\end{array}$ \\
\hline & 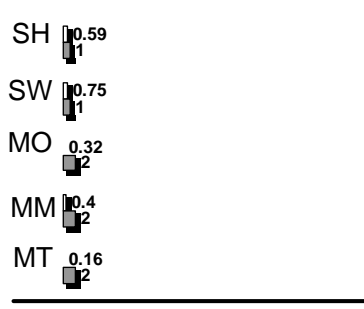 & 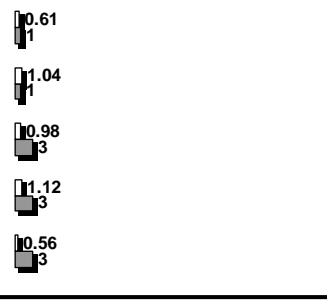 & 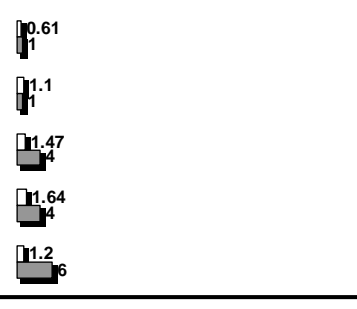 & 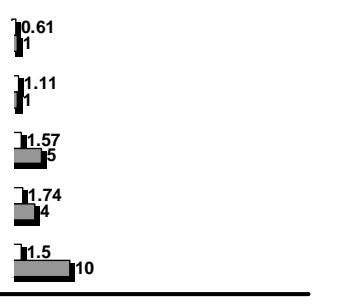 \\
\hline 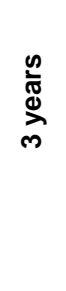 & 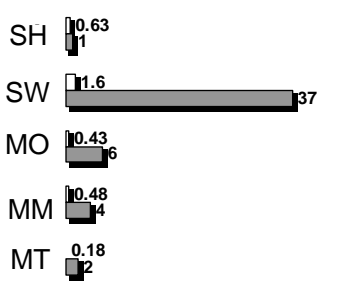 & 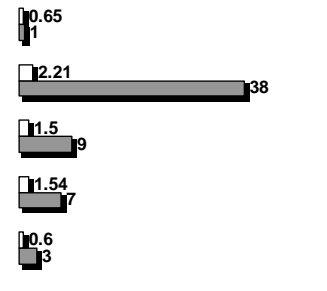 & 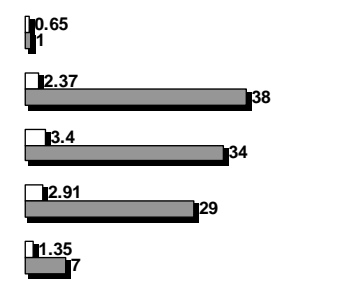 & 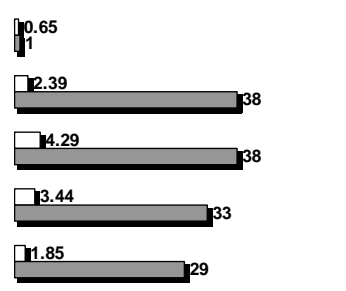 \\
\hline 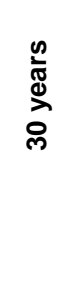 & 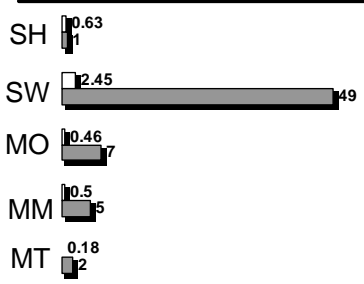 & 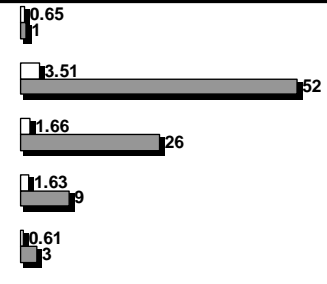 & 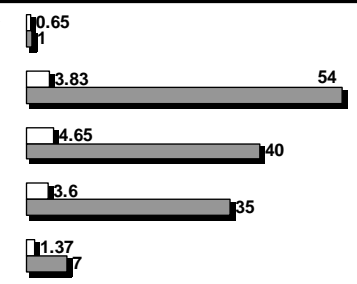 & 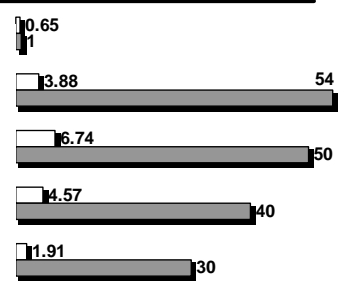 \\
\hline
\end{tabular}


Figure S4: Temporal profile of the eACP for the bell curve emission scenario.

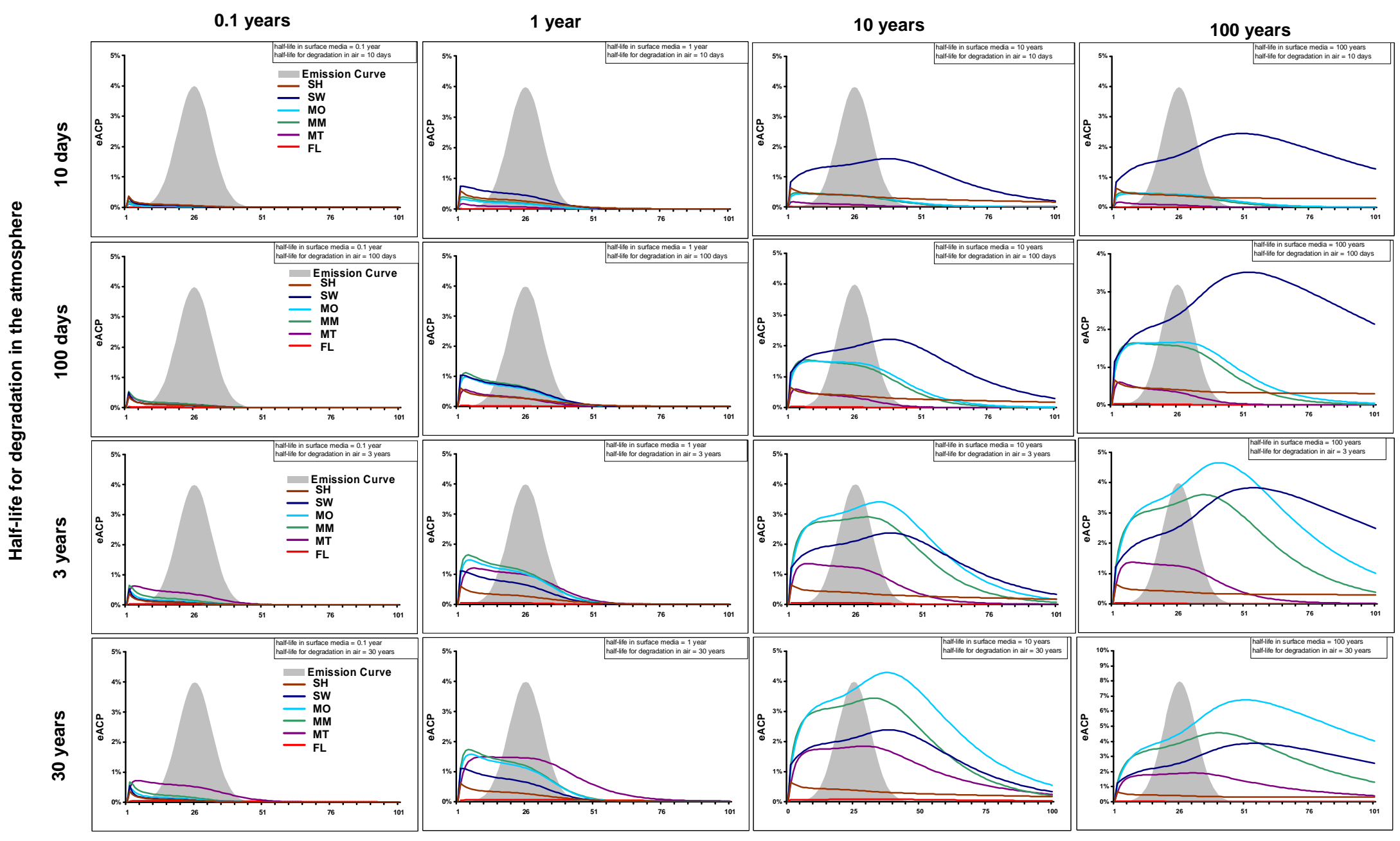


Figure S5: Steady-state emission scenario (solid grey bar indicates time to maximum eACP, white bar indicates the value of the maximum eACP, for chemicals SH, SW, MO, MM, and MT.)

Reference half-life for degradation in surface media

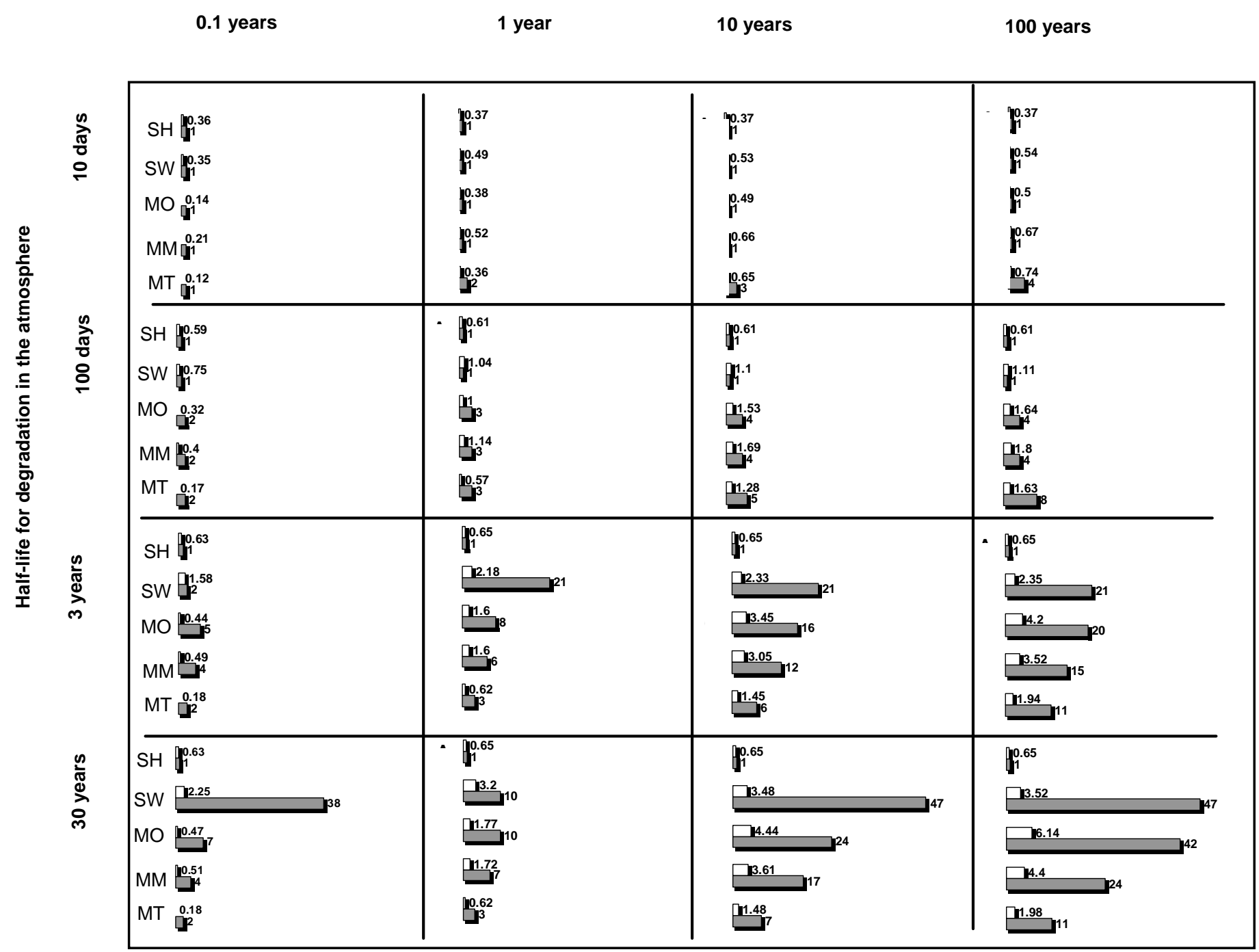


Figure S6: Temporal profile of the eACP for the steady-state emission scenario.

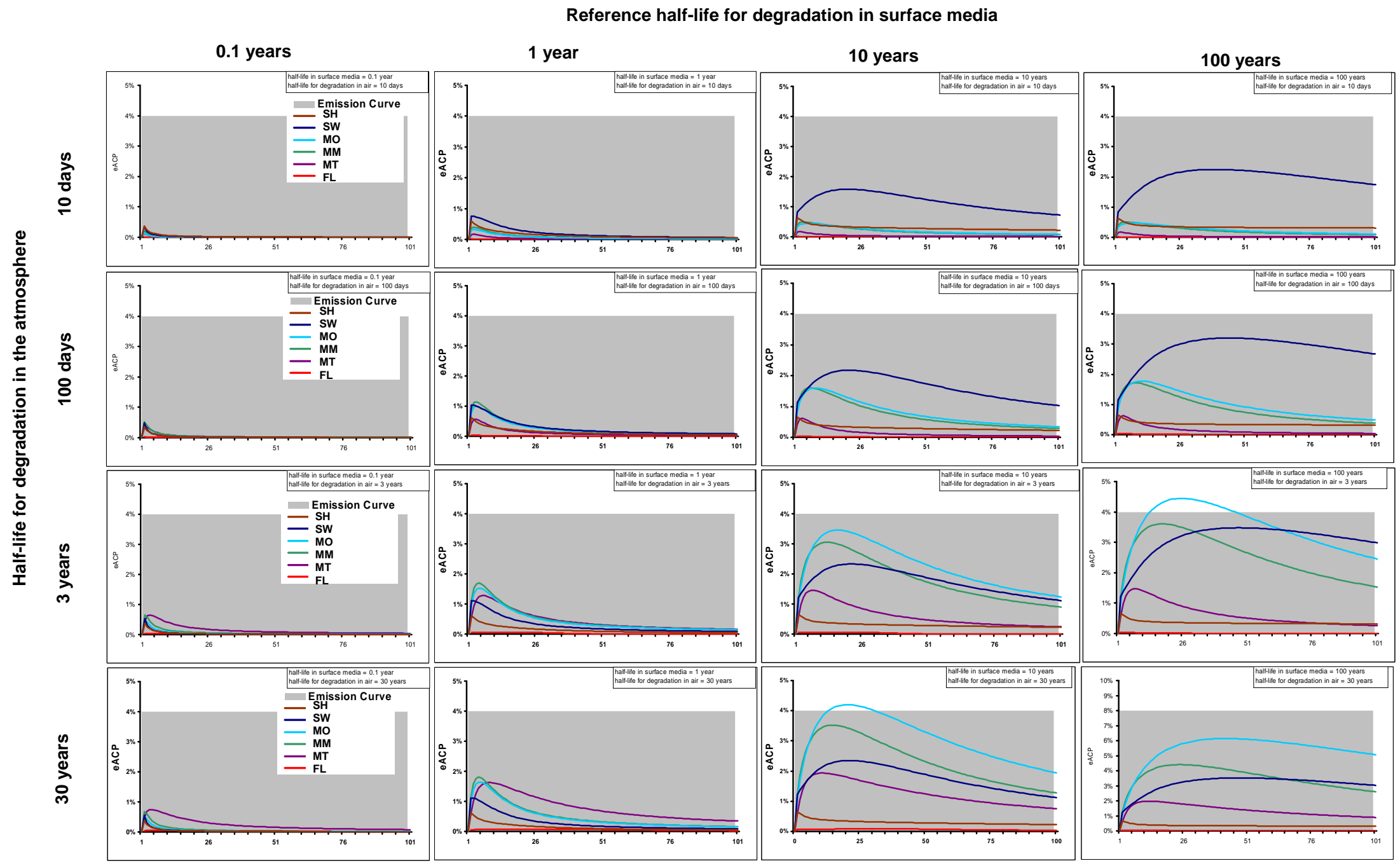


Figure S7: Temporal profile of the eACP for SW, MO, and MM for the bell curve emission scenario. For each plot the $\mathrm{t}_{1 / 2}$ in air is held constant, as indicated along the left-hand side, and the influence of the $t_{1 / 2}$ in surfaces is illustrated (note the similar behavior between $\mathrm{MO}$ and $\mathrm{MM}$ ).

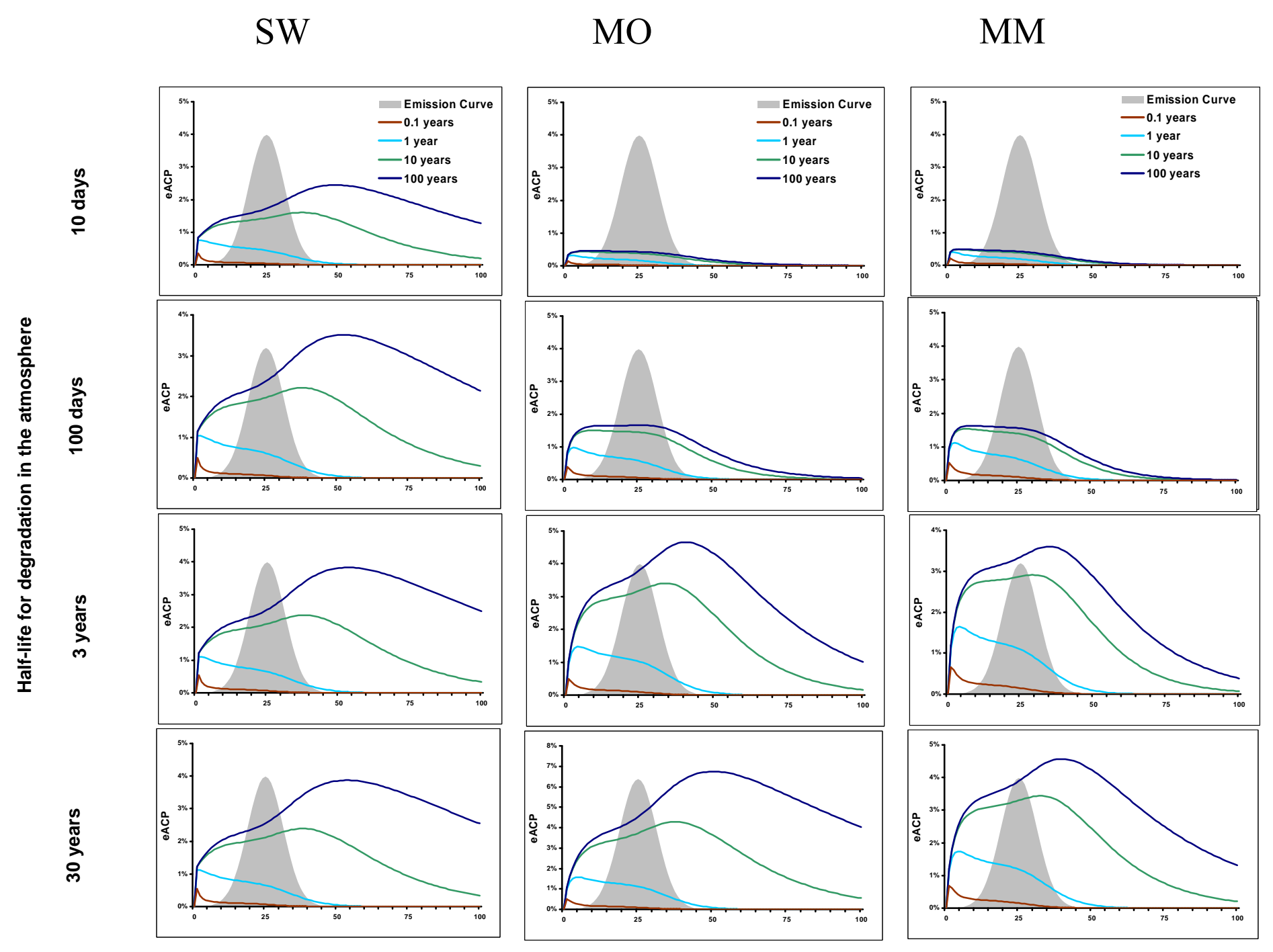


Figure S8 Influence of setting the oceanic advection term to zero on the eACP for the most persistent SW and MM.

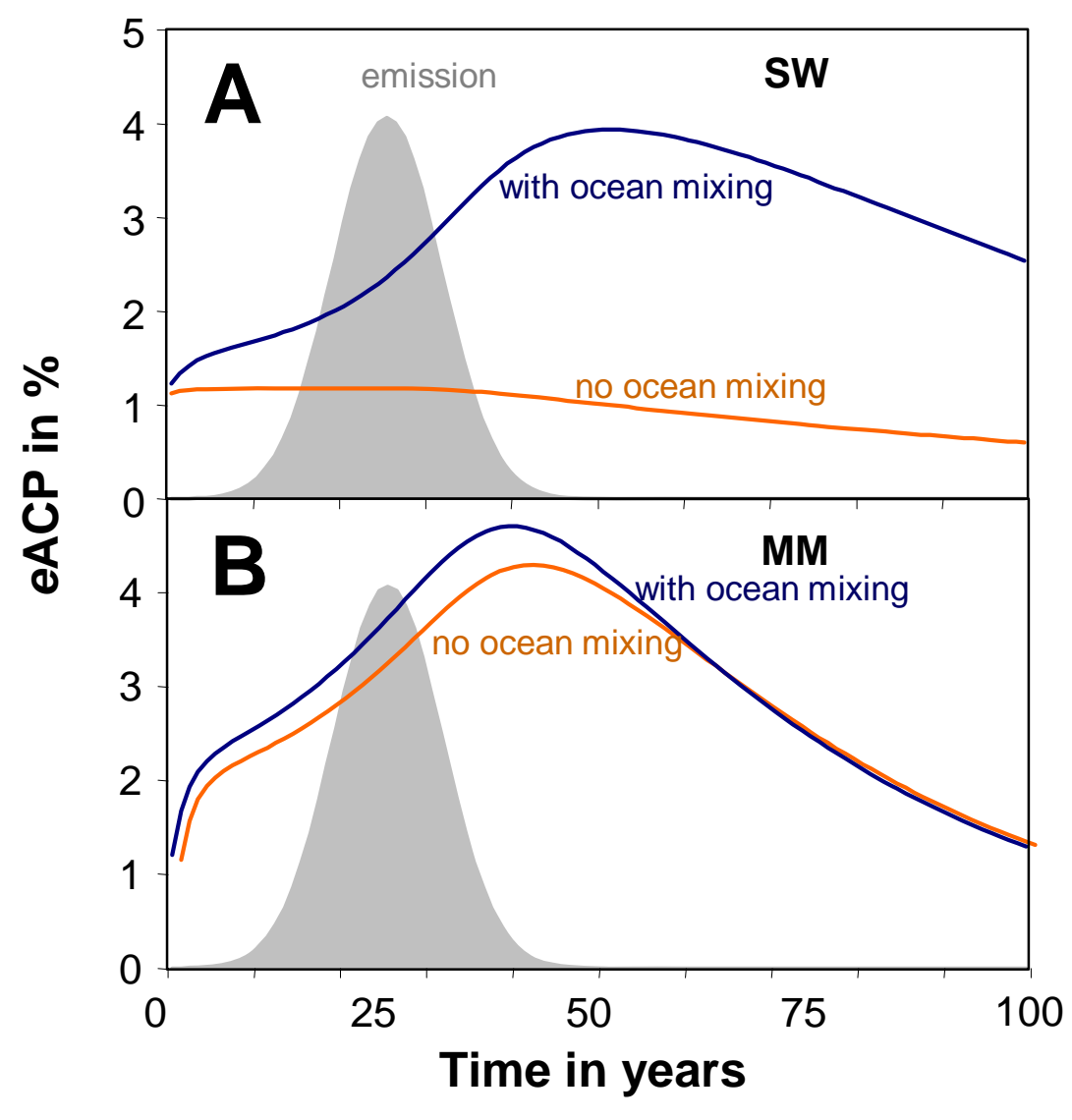

